\title{
HUMAN PARASITISM BY Rhipicephalus sanguineus sensu lato (ACARI: IXODIDAE) IN MATO GROSSO DO SUL, WEST-CENTRAL BRAZIL
}

\section{Parasitismo humano por Rhipicephalus sanguineus sensu lato (ACARI: IXODIDAE) no Mato Grosso do Sul, Centro-Oeste do Brasil}

\author{
Igor Cunha Lima ACOSTA ${ }^{1}$; Thiago Fernandes MARTINS ${ }^{1}$; Marcelo Bahia LABRUNA ${ }^{1}$ \\ ${ }^{1}$ Universidade de São Paulo, Faculdade de Medicina Veterinária e Zootecnia, Departamento de Medicina \\ Veterinária Preventiva e Saúde Animal, São Paulo - SP, Brazil
}

\begin{abstract}
Human parasitism by the brown dog tick Rhipicephalus sanguineus sensu lato (s. 1.), an important parasite in medical and veterinary sciences, is only rarely reported in the American continent. The present investigation reports a $R$. sanguineus s. l. male tick parasitizing a human in the city of Campo Grande, State of Mato Grosso do Sul, west-central Brazil. This observation is of public health relevance, since R. sanguineus s. l. ticks are known as vectors of spotted fever group rickettsiae to dogs and humans.
\end{abstract}

Keywords: Rhipicephalus sanguineus. Tick. Human parasitism.

\section{Resumo}

O parasitismo humano pelo carrapato marrom do cão, Rhipicephalus sanguineus sensu lato (s. 1.), um importante parasita para a saúde pública e veterinária, é raramente relatado no continente americano. Este trabalho relata o registro de um macho de R. sanguineus s. l. parasitando um humano na cidade de Campo Grande, estado do Mato Grosso do Sul, no Centro-Oeste do Brasil. Essa observação é relevante para a saúde pública, uma vez que os carrapatos desse complexo são conhecidos como vetores de riquétsias do grupo da febre maculosa para cães e humanos.

Palavras-chave: Rhipicephalus sanguineus. Carrapato. Parasitismo humano.

Correspondence to:

Igor C. L. Acosta

Universidade de São Paulo, Faculdade de Medicina Veterinária e

Zootecnia, Departamento de Medicina Veterinária Preventiva e

Saúde Animal

Av. Prof. Orlando Marques de Paiva, 87

CEP 05508-270, São Paulo, SP, Brazil

E-mail: igorclacosta@gmail.com

Received: 13/06/2016

Approved: 12/01/2017

Rhipicephalus sanguineus sensu lato (s. 1.) (Latreille, 1806) (Acari: Ixodidae), also known as the brown dog tick, is an important parasite in medical and veterinary sciences, since it is a vector and reservoir of many human and animal pathogens (DANTAS-TORRES; OTRANTO, 2015). Recent studies based on molecular, biological, and morphological analyses have indicated that the taxon $R$. sanguineus is represented by two or more species (OLIVEIRA et al., 2005; SZABÓ et al., 2005; BURLINI et al., 2010; MORAESFILHO et al., 2011; LEVIN et al., 2012; NAVA et al., 2012;
DANTAS-TORRES et al., 2013). Therefore, while this taxonomic problem remains unsolved, all ticks that fit taxonomically with ' $R$. sanguineus' should be called $R$. sanguineus s. 1. or $R$. sanguineus species complex (NAVA et al., 2015).

In Brazil, the Brazilian spotted fever (BSF) is caused by Rickettsia rickettsii, and the novel Brazilian spotted fever is caused by a Rickettsia parkeri-like agent. Both have been detected in $R$. sanguineus s. 1. ticks (ROZENTAL et al., 2002; CUNHA et al., 2009; MORAES-FILHO et al., 2009; PACHECO et al., 2011; MEDEIROS et al., 2011; OGRZEWALSKA et al., 2012; ALMEIDA et al., 2013). While human parasitism by $R$. sanguineus s.l. is not common in Brazil, a few confirmed cases have been reported in the states of Pernambuco, Goiás, Rio de Janeiro, Pará, and Rio Grande do Sul (DANTAS-TORRES et al., 2006; LOULY et al., 2006; SERRA-FREIRE, 2010; SERRAFREIRE et al., 2011; MENTZ et al., 2016). Extending previous information, the objective of this study was to 
report the finding of a $R$. sanguineus s. l. parasitizing a human in Campo Grande, State of Mato Grosso do Sul, Brazil.

On February 2016, by the end of the day working in his farm with domestic animals (horses, cattle, and dogs), a 27-year-old veterinarian felt a little discomfort on his abdominal region. Analyzing the nuisance, he found a brown tick attached to his skin (Figure 1). The tick was collected alive and sent to the laboratory, where it was morphologically identified as a male $R$. sanguineus $\mathrm{s}$. 1., following Barros-Batesti et al. (2006) and Nava et al. (2015). The specimen was deposited in the tick collection "Coleção Nacional de Carrapatos" under accession number CNC-3276.

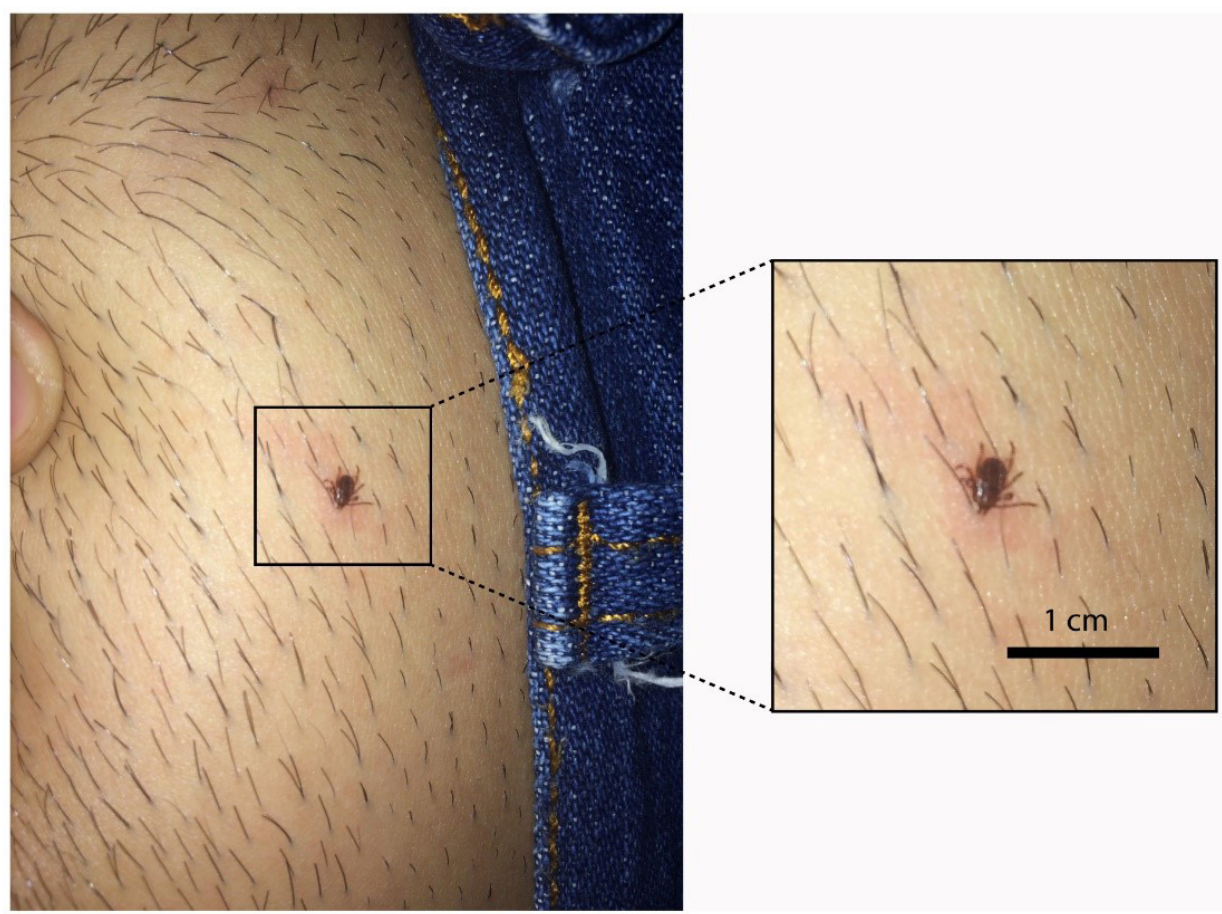

Figure 1 - A brown dog tick (Rhipicephalus sanguineus sensu lato) parasitizing a human in Campo Grande, Mato Grosso do Sul, west-central Brazil

Considering the biogeographic classification according to Moraes-Filho et al. (2009), the present record of human parasitism by $R$. sanguineus s. 1 . in the Mato Grosso do Sul state corresponds to a tick included in the tropical species. The authors showed that the taxon $R$. sanguineus s. 1. is represented in Brazil by two genetically distinct populations referred to as either 'tropical' or 'temperate' lineages. While the temperate species was only reported in the state of Rio Grande do Sul, the tropical species was found throughout the other regions of the country, including the west-central region (MORAES-FILHO et al., 2009). This observation supports previous records of other tropical populations of $R$. sanguineus s. 1. parasitizing humans in the states of Pernambuco, Goiás, Rio de Janeiro, and Pará (DANTAS-TORRES et al., 2006; LOULY et al., 2006; SERRA-FREIRE et al., 2011). On the other hand, there is at least one record of human parasitism by $R$. sanguineus s. 1. temperate species in Rio Grande do Sul, southern Brazil (MENTZ et al., 2016).

The report of human parasitism by $R$. sanguineus s. 1 . is of public health relevance, since ticks of this complex are known as vectors of Rickettsia spp. of the spotted fever group for dogs and also humans (DANTAS-TORRES; OTRANTO, 2015). In fact, ticks of the tropical species have been found infected with $R$. rickettsii in the states of Minas Gerais, Rio de Janeiro, and São Paulo (ROZENTAL et al., 2002; CUNHA et al., 2009; MORAES-FILHO et al., 2009; PACHECO et al., 2011; OGRZEWALSKA et al., 2012), as well as in Mato Grosso do Sul (ALMEIDA et al., 2013). Therefore, considering the close relationship between men and this tick species and its capacity to harbor and transmit Rickettsia, human bites should be monitored. 


\section{References}

ALMEIDA, R. F.; GARCIA, M. V.; CUNHA, R. C.; MATIAS, J.; SILVA, E. A.; MATOS, M. F. C.; ANDREOTTI, R. Ixodid fauna and zoonotic agents in ticks from dogs: first report of Rickettsia rickettsii in Rhipicephalus sanguineus in the state of Mato Grosso do Sul, mid-western Brazil. Experimental and Applied Acarology, v. 60, n. 1 p. 63-72, 2013. doi: 10.1007/s10493-012-9641-y.

BARROS-BATTESTI, D. M.; ARZUA, M.; BECHARA, G. H. Carrapatos de importância médico-veterinária da região neotropical: um guia ilustrado para identificação de espécies. São Paulo: Vox; International Consortium on Ticks and Tick-borne Diseases (ICTTD-3); Butantan, 2006. 223 p.

BURLINI, L.; TEIXEIRA, K. R.; SZABÓ, M. P.; FAMADAS, K. M. Molecular dissimilarities of Rhipicephalus sanguineus (Acari: Ixodidae) in Brazil and its relation with samples throughout the world: is there a geographical pattern? Experimental and Applied Acarology, v. 50, n. 2, p. 361-374, 2010. doi: 10.1007/s10493-009-9321-8.

CUNHA, N. C.; FONSECA, A. H.; REZENDE, J.; ROZENTAL, T.; FAVACHO, A. R. M.; BARREIRA, J. D.; MASSARD, C. L.; LEMOS, E. R. S. First identification of natural infection of Rickettsia rickettsii in the Rhipicephalus sanguineus tick, in the State of Rio de Janeiro. Pesquisa Veterinária Brasileira, v. 29, n. 2, p. 105-108, 2009. doi: 10.1590/S0100-736X2009000200003.

DANTAS-TORRES, F.; FIGUEREDO, L. A.; BRANDÃOFILHO, S. P. Rhipicephalus sanguineus (Acari: Ixodidae), the brown dog tick, parasitizing humans in Brazil. Revista do Instituto de Medicina Tropical v. 39, n. 1 p. 64-67, 2006. doi: 10.1590/S0037-86822006000100012.

DANTAS-TORRES, F.; LATROFA, M. S.; ANNOSCIA, G.; GIANELLI, A.; PARISI, A.; OTRANTO, D. Morphological and genetic diversity of Rhipicephalus sanguineus sensu lato from the New and Old Worlds. Parasites and Vectors, v. 6, p. 213, 2013. doi: 10.1186/1756-3305-6-213.

DANTAS-TORRES, F.; OTRANTO, D. Further thoughts on the taxonomy and vector role of Rhipicephalus sanguineus group ticks. Veterinary Parasitology, v. 208, n. 1-2, p. 9-13, 2015. doi: 10.1016/j.vetpar.2014.12.014.

LEVIN, M. L.; STUDER, E.; KILLMASTER, L.; ZEMTSOVA, G.; MUMCUOGLU, K. Y. Crossbreeding between different geographical populations of the brown dog tick, Rhipicephalus sanguineus (Acari: Ixodidae). Experimental and Applied Acarology, v. 58, n. 1, p. 5168, 2012. doi: 10.1007/s10493-012-9561-x.

LOULY, C. C. B.; FONSECA, I. N.; OLIVEIRA, V. F.; BORGES, L. M. F. Ocorrência de Rhipicephalus sanguineus em trabalhadores de clínicas veterinárias e canis, no município de Goiânia, GO. Ciência Animal Brasileira, v. 7, n.1, p. 103-106, 2006.

MEDEIROS, A. P.; SOUZA, A. P.; MOURA, A. B.; LAVINA, M. S.; BELLATO, V.; SARTOR, A. A.; NIERIBASTOS, F. A.; RICHTZENHAIN, L. J.; LABRUNA, M. B. Spotted fever group Rickettsia infecting ticks (Acari: Ixodidae) in the state of Santa Catarina, Brazil. Memórias do Instituto Oswaldo Cruz, v. 106, n. 8, p. 926-930, 2011. doi: 10.1590/S0074-02762011000800005.

MENTZ, M. B.; TROMBKA, M.; SILVA, G. L.; SILVA, C. E. Rhipicephalus sanguineus (Acari: Ixodidae) biting a human being in Porto Alegre city, Rio Grande do Sul, Brazil. Revista do Instituto de Medicina Tropical de São Paulo, v. 58, 2016. doi: 10.1590/S16789946201658035.

MORAES-FILHO, J.; MARCILI, A.; NIERI-BASTOS, F. A.; RICHTZENHAIN, L. J.; LABRUNA, M. B. Genetic analysis of ticks belonging to the Rhipicephalus sanguineus group in Latin America. Acta Tropica, v. 117, n. 1, p. 51-55, 2011. doi: 10.1016/j. actatropica.2010.09.006.

MORAES-FILHO, J.; PINTER, A.; PACHECO, R. C.; GUTMANN, T. B.; BARBOSA, S. O.; GONZÁLES, M. A. R. M.; MURARO, M. A.; CECÍLIO, S. R. M.; LABRUNA, M. B. New epidemiological data on Brazilian spotted fever in an endemic area of the state of São Paulo, Brazil. VectorBorne and Zoonotic Diseases, v. 9, n. 1, p. 73-78, 2009. doi: 10.1089/vbz.2007.0227. 
NAVA, S.; ESTRADA-PEÑA, A.; PETNEY, T.; BEATI, L.; LABRUNA, M. B.; SZABÓ, M. P. J.; VENZAL, J. M.; MASTROPAOLO, M.; MANGOLD, A. J.; GUGLIELMONE, A. A. The taxonomic status of Rhipicephalus sanguineus (Latreille, 1806). Veterinary Parasitology, v. 208, n. 1-2, p. 2-8, 2015. doi: 10.1016/j.vetpar.2014.12.021.

NAVA, S.; MASTROPAOLO, M.; VENZAL, J. M.; MANGOLD, A. J.; GUGLIELMONE, A. A. Mitochondrial DNA analysis of Rhipicephalus sanguineus sensu lato (Acari: Ixodidae) in the Southern Cone of South America. Veterinary Parasitology, v. 190, n. 3-4, p. 547-555, 2012. doi: 10.1016/j.vetpar.2012.06.032.

OGRZEWALSKA, M.; SARAIVA, D. G.; MORAESFILHO, J.; MARTINS, T. F.; COSTA, F. B.; PINTER, A.; LABRUNA, M. B. Epidemiology of Brazilian spotted fever in the Atlantic Forest, state of São Paulo, Brazil. Parasitology, v. 139, n. 10, p. 1283-1300, 2012. doi: 10.1017/ S0031182012000546.

OLIVEIRA, P. R.; BECHARA, G. H.; DENARDI, S. E.; SAITO, K. C.; NUNES, E. T.; SZABÓ, M. P. J.; MATHIAS, M. I. C. Comparison of the external morphology of Rhipicephalus sanguineus (Latreille, 1806) (Acari: Ixodidae) ticks from Brazil and Argentina. Veterinary Parasitology, v. 129, n. 1-2, p. 139-147, 2005. doi: 10.1016/j. vetpar.2005.01.001.

PACHECO, R. C.; MORAES-FILHO, J.; GUEDES, E.; SILVEIRA, I.; RICHTZENHAIN, L. J.; LEITE, R.
C.; LABRUNA, M. B. Rickettsial infections of dogs, horses and ticks in Juiz de Fora, southeastern Brazil, and isolation of Rickettsia rickettsii from Rhipicephalus sanguineus ticks. Medical and Veterinary Entomology, v. 25 , n. 2, p. 148-155, 2011. doi: 10.1111/j.13652915.2010.00915.x.

ROZENTAL, T.; BUSTAMANTE, M. C.; AMORIM, M.; SERRA-FREIRE, N. M.; LEMOS, E. R. S. Evidence of spotted fever group rickettsiae in state of Rio de Janeiro, Brazil. Revista do Instituto de Medicina Tropical de São Paulo, v. 44, n. 3, p. 155-158, 2002. doi: 10.1590/S003646652002000300008.

SERRA-FREIRE, N. M. Occurrence of ticks (Acari: Ixodidae) on human hosts, in three municipalities in the State of Pará, Brazil. Revista Brasileira de Parasitologia Veterinária, v. 19, n. 3, p. 141-147, 2010. doi: 10.1590/S198429612010000300003.

SERRA-FREIRE, N. M.; SENA, L. M. M.; BORSOI, A. B. P. Parasitismo humano por carrapatos na Mata Atlântica, Rio de Janeiro, Brasil. EntomoBrasilis, v. 4, n. 2, p. 6772, 2011.

SZABÓ, M. P. J.; MANGOLD, A. J.; JOÃO, C. F.; BECHARA, G. H.; GUGLIELMONE, A. A. Biological and DNA evidence of two dissimilar populations of the Rhipicephalus sanguineus tick group (Acari: Ixodidae) in South America. Veterinary Parasitology, v. 130, n. 1-2, p. 131-140, 2005. doi: 10.1016/j.vetpar.2005.03.008. 